\title{
Sapodilla (Manilkara sapota L. V. Rogen, Achras sapota Linn.) variety trials at southern Puerto Rico'
}

\author{
Rubén Vélez-Colón, Isabel Beauchamp de Caloni and \\ Sonia Martínez-Garrastazú...
}

\begin{abstract}
Seventeen varieties of sapodilla (Manilkara sapota L. V. Rogen, Achras sapota Linn.) were planted in 1971 at the Fortuna Experiment Substation, Juana Díaz, Puerto Rico, following a randomized block layout with three replications. During the seasons of 1982-83 through 1986-87 (December through April), the fruits were harvested for evaluation as to appearance, flavor, brix, $\mathrm{pH}$, acidity, \% reducing sugars, \% total sugars, number of fruits per tree, yield $(\mathrm{kg})$ and average fruit weight per variety $(\mathrm{g})$. In spite of the fact that the data were not statistically analyzed because of many observed variations, valuable information was obtained and is herein reported.

Several varieties achieved acceptability, depending on the criterion used. However, the Larsen variety appears to be one of the best producers as well as the highest rated as to flavor. Russel was preferred as to appearance by the tasting panel. Other varieties were found acceptable in terms of the various parameters studied, such as Jamaica 5, Prolific, Morning Star and Timothe.
\end{abstract}

\section{RESUMEN}

Evaluación de variedades de níspero (Manilkara sapota L. V. Rogen) en Puerto Rico

Se evaluaron 17 variedades de níspero en la región costera semiárida del sur de Puerto Rico, Subestación Experimental Agrícola de Fortuna, Juana Díaz. Las variedades se replicaron tres veces en un diseño de bloques al azar. La investigación se hizo a fines de evaluar la calidad de las frutas en relación a sabor, apariencia, Brix, pH, acidez, azúcares reductoras y azúcares totales. Se tomaron datos en cuanto al número de frutas producidas por variedad, peso de la producción, y peso promedio por fruta, tanto para las frutas comerciales como para las no comerciales. Los datos no se analizaron estadísticamente dada la gran variación observada, pero no por eso dejan de ser valiosos.

La variedad Russel resultó ser la de mejor apariencia. La variedad Larsen resultó, en promedio, la de mejor sabor. La variedad Larsen fue además, junto a la variedad Blackwood, la mejor productora, tanto en

'Manuscript submitted to Editorial Board 7 March 1989.

"Research Assistant, Fortuna Substation, Juana Díaz, Puerto Rico; Food Researcher, Food Technology Laboratory, Río Piedras, Puerto Rico, and Research Assistant, Horticulture Department, Agricultural Experiment Station, University of Puerto Rico, Mayagüez Campus.

${ }^{3}$ We appreciate the collaboration of Ms. Anita Nazario Ruiz, in the chemical analyses conducted at the Food Technology Laboratory. 
cuanto al número de frutas como al peso de la producción por árbol. Las frutas mostraron gran variación en cuanto a las características evaluadas. Tomando en consideración los parámełros para medir la calidad de las frutas, las variedades más prometedoras resultaron ser: Larsen, Jamaica 5, Russel, Prolific, Morning Star y Timothe.

\section{INTRODUCTION}

Sapodilla (Manilkara sapota L. V. Rogen, Achras sapota Linn.) is a tropical fruit which possibly originated in the Yucatán peninsula of Mexico. It is known by different names such as mespel (Virgin Islands), níspero (Puerto Rico), sapote (Cuba), zapote, chicozapote, zapote chico, chicle, zapotillo (Mexico), muyozapot (El Salvador), sapodilla (United States), naseberry (British West Indies), dilly (Bahamas), sapotille, sapotillier (French West Indies), mispu, mispel, sapodille (Dutch West Indies), sapotille, sapatija, mispelboon (Surinam), and sapoti or sapotilha (Brazil) (4). Sapodilla is the source of the main ingredient for the preparation of bubble gum and can be used in the elaboration of juice, syrup and ice cream. It may also be dehydrated (1), frozen (8), or used as a fresh fruit.

The sapodilla tree may reach over twenty meters high when propagated by seeds. It resists long periods of drought, although it may require irrigation at critical times. This tree is cultivated extensively on the American continent from Mexico to Brazil and the southern tip of Florida (6) as well as in other tropical zones of the world. It produces a fruit botanically classified as a berry, which may be round or elongated, with a harsh brown skin. The pulp is usually sweet with a pleasant flavor. A fruit may have up to twelve seeds, or none at all. They are black, flat, smooth and eliptic, with a white scar in the hilum (9).

The chemical composition of the sapodilla fruit has been studied in India, Venezuela and the United Kingdom $(2,3,5,7,8)$. Rivas and Martos (8) presented some data related to $\mathrm{pH}$ (5.35), total acidity $(0.26 \%)$, reducing sugars $(11.08 \%)$, total sugars $(13.8 \%)$ and other parameters. Ingle et al. (3) also reported data on reducing sugars (4.38), total sugars (6.57) and acidity (0.2\%).

\section{MATERIALS AND METHODS}

Seventeen sapodilla varieties were planted at $9 \times 9 \mathrm{~m}$ spacing in July 1971 at the Fortuna Agricultural Experiment Substation, in the southern semiarid coastal region of Puerto Rico. A randomized block design with five replications was used, although because of the death of some trees throughout the years, replications were eventually reduced to three. New trees were not planted so as not to introduce a new variable (date of planting). The varieties evaluated were Adelaide, Arus, Blackwood, Bocksberg, Jamaica 1, Jamaica 3, Jamaica 4, Jamaica 5, Jamaica 8, Jamaica 10, Larsen, Mary Fancy, Morning Star, Ponce, Prolific, Russel and Timothe (fig. 1). 


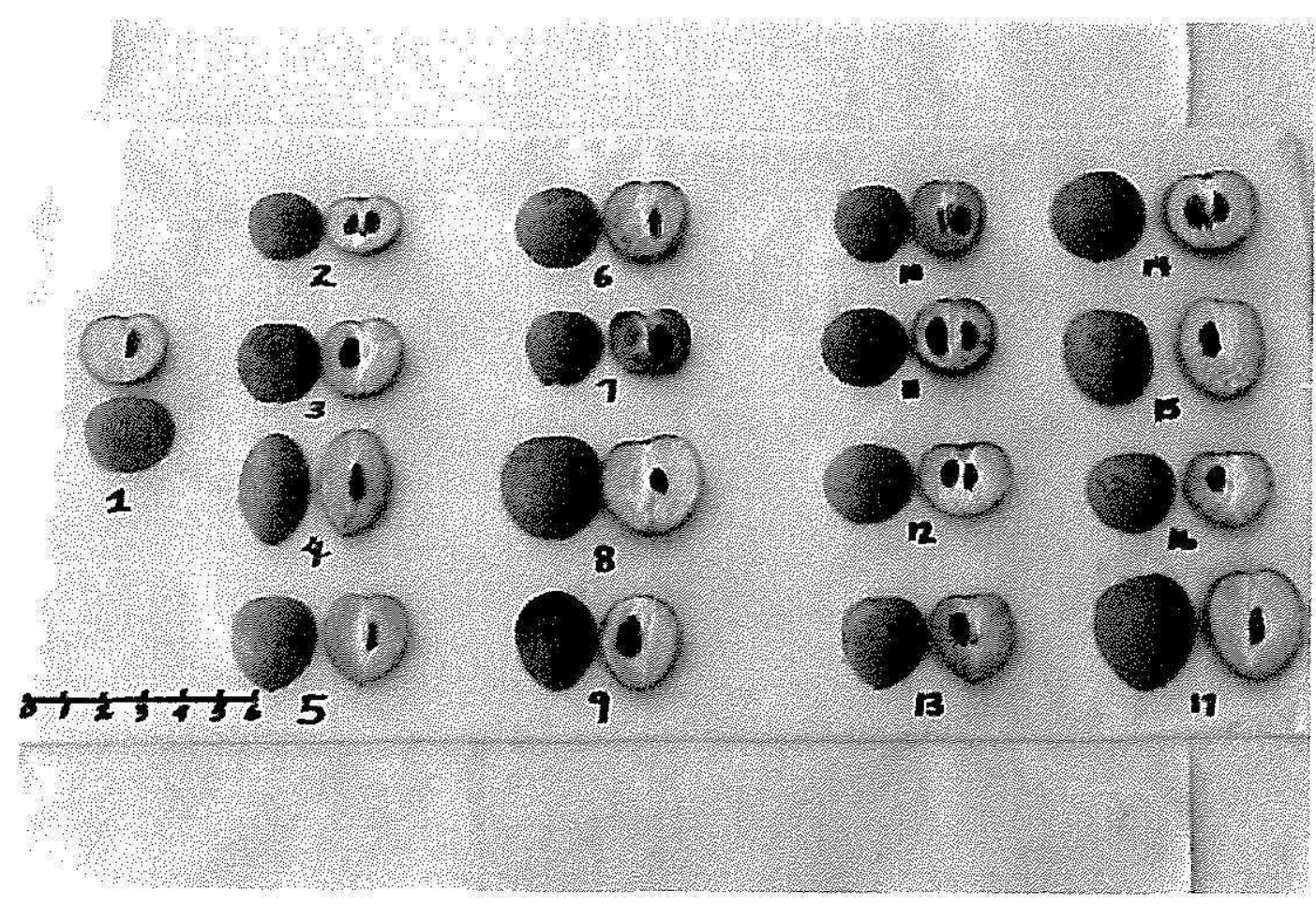

FIG. 1.-Fruits of the seventeen sapodilla varieties evaluated in this experiment.

Legend:
1. Timothe
10. Jamaica 8
2. Adelaide
11. Jamaica 10
3. Arus
12. Larsen
4. Blackwood
13. Mary Fancy
5. Bocksberg
14. Morning Star
6. Jamaica 1
15. Ponce
7. Jamaica 3
16. Prolific
8. Jamaica 4
17. Russel
9. Jamaica

From December through April 1983-84, 1985-86 and 1986-87, samples of fruits were sent to the Food Technology Laboratory of the Agricultural Experiment Station at Río Piedras for sensory evaluation of the seventeen sapodilla varieties in regard to flavor and appearance. Each sample was evaluated by a group of seven to eleven members of a taste panel in at least two sessions (table 1).

\section{RESULTS AND DISCUSSION}

Because of the great variability observed, the data obtained were not statistically analyzed. In spite of that fact, information was obtained that could be of value to other researchers, as well as to Extension workers and farmers. Awareness of this limitation is important in interpreting the data herein reported. 
TABLE 1.-Sensory evaluation of sapodilla from 17 varieties grown in southern Puerto Rico

\begin{tabular}{|c|c|c|c|c|c|c|c|c|}
\hline \multirow[b]{2}{*}{ Variety } & \multicolumn{3}{|c|}{ Appearance } & \multirow[b]{2}{*}{ Ave. } & \multicolumn{3}{|c|}{ Flavor } & \multirow[b]{2}{*}{ Ave } \\
\hline & 1984 & 1986 & 1987 & & 1984 & 1986 & 1987 & \\
\hline Adelaide & 0.25 & - & 0.63 & .44 & 1.23 & - & 0.52 & .88 \\
\hline Arus & 1.72 & 0.78 & 0.93 & 1.14 & 1.62 & -0.22 & 1.19 & .86 \\
\hline Blackwood & 1.33 & - & 0.88 & 1.11 & 0.94 & - & 0.70 & .55 \\
\hline Bocksberg & 1.38 & 0.78 & 0.84 & 1.00 & 0.91 & 0.00 & 0.08 & .33 \\
\hline Jamaica 1 & 1.07 & 1.00 & 1.37 & 1.15 & 0.88 & 0.48 & 0.26 & .54 \\
\hline Jamaica 3 & 0.43 & 1.57 & 0.77 & .92 & 0.66 & 1.09 & 1.22 & .99 \\
\hline Jamaica 4 & 0.66 & - & 1.45 & 1.06 & 0.73 & - & 0.80 & .77 \\
\hline Jamaica 5 & 1.18 & 1.20 & 1.40 & 1.26 & 1.27 & 0.98 & 1.25 & 1.17 \\
\hline Jamaica 8 & 0.41 & 0.59 & 1.02 & .67 & 1.03 & 0.71 & 0.26 & .49 \\
\hline Jamaica 10 & 0.32 & 0.75 & 0.89 & .65 & 0.30 & 0.50 & 1.00 & .60 \\
\hline Larsen & 0.50 & 1.22 & 1.11 & .94 & 1.42 & 1.00 & 1.56 & 1.33 \\
\hline Mary Fancy & 1.06 & -0.15 & 0.91 & .61 & 1.22 & -0.50 & 0.68 & .47 \\
\hline Morning Star & 0.79 & 1.50 & 1.32 & 1.20 & 1.10 & 0.83 & 1.03 & 1.01 \\
\hline Ponce & 1.10 & 0.67 & 0.91 & .89 & 1.62 & 0.80 & 0.23 & .88 \\
\hline Prolific & 1.70 & 1.26 & 0.93 & 1.30 & 0.95 & 0.86 & 0.72 & .84 \\
\hline Russel & 1.45 & 1.26 & 1.34 & 1.35 & 1.35 & 0.31 & 0.89 & .85 \\
\hline 'Timothe & 1.05 & 1.09 & 0.89 & 1.01 & 1.23 & 0.85 & 1.00 & 1.03 \\
\hline Variety Averages & .965 & .965 & 1.035 & & 1.086 & .549 & .76 & \\
\hline
\end{tabular}

$1+2,-2$ scale $;+2.0=$ Highly acceptable, $+1.0=$ acceptable, $0=$ questionable; $-1.0=$ Slightly not acceptable, $-2.0=$ not acceptable. 
Data in table 1 indicates that some varieties tend to be inconsistent from year to year in regard to their appearance, taste, or both. Arus variety, for example, obtained 1.72 out of a possible maximum score of 2.0 in regard to appearance in 1984, whereas in 1986 it obtained only 0.78. Jamaica 3, Jamaica 8, Morning Star and Larsen showed a similar situation in regard to appearance, whereas Adelaide, Jamaica 3, Jamaica 8 and Russel showed variation in taste. Mary Fancy variety, on the other hand, may be considered an exception. It received a rating of 1.06 in regard to appearance in 1984 and 0.91 in 1987, but only -0.15 in 1985-86; thus it was rejected by the evaluation panel. A similar situation may be acknowledged in the case of Arus in regard to taste. These variations may be attributed to the attack of pests or mechanical damage at harvest.

The Russel variety consistently shows the best appearance; other varieties may show a better appearance in a given year, but are unable to repeat that performance in successive years.

Other varieties that show an acceptable appearance are, from highest to lowest, Prolific, Jamaica 5, Morning Star, Jamaica 1, Arus, Blackwood, Jamaica 4, Timothe and Bocksberg (table 1). The lowest average for appearance was obtained by Adelaide variety, 0.44 . The Larsen variety, whose rating as to appearance did not average above 1.00 , was the best variety as to taste, with an average of 1.33. This three-year average was the best among the 17 varieties evaluated. Furthermore, Larsen showed the highest taste score in 1987, when it obtained 1.56. Russel, the variety which showed the highest score as to appearance, was inconsistent in taste; its three-year average was 0.85 .

Other varieties with high score values in relation to the taste criterion were Jamaica 5, Timothe and Morning Star. The lowest average in regard to taste was obtained by Bocksberg variety, with 0.33.

Environment seemed to have a profound effect on the quality of fruits produced every year. In 1984, with a variety average of 1.086 , the taste was generally better than in 1986 (variety average of 0.549 ). In 1987, this average was not as high as in 1984, but it was slightly better than in 1986. Variety averages in relation to appearance were more consistent.

The recorded averages of three years showed as unacceptable in appearance all varieties (an average below 1.00) except Arus, Blackwood, Bocksberg, Jamaica 1, Jamaica 4, Jamaica 5, Morning Star, Prolific, Russel and Timothe. Jamaica 5, Larsen, Morning Star and Timothe were the only varieties with acceptable taste. That is, varieties Adelaide, Jamaica 3, Jamaica 8, Jamaica 10, Larsen, Mary Fancy and Ponce scored less than 1.00 in appearance, whereas varieties Adelaide, Arus, Blackwood, Bocksberg, Jamaica 1, Jamaica 3, Jamaica 4, Jamaica 8, Jamaica 10, Mary Fancy, Ponce, Prolific and Russel scored less than 1.00 in relation to the taste.

Table 2 presents the chemical analyses of the 17 sapodilla varieties. 
TABLE 2.-Chemical analysis of sapodilla fruits from 17 varieties grown in southem Puerto Rico

\begin{tabular}{lccccc}
\hline \multirow{2}{*}{ Variety } & Brix & & & \multicolumn{2}{c}{ Sugars } \\
& & & Acidity & Reducing & Total \\
\hline Adelaide & 23.1 & 4.96 & 0.076 & 15.19 & 19.61 \\
Arus & 20.4 & 5.00 & 0.75 & 12.97 & 18.95 \\
Blackwood & 18.0 & 5.15 & 0.76 & 12.63 & 15.16 \\
Bocksberg & 15.2 & 4.91 & 0.109 & 8.95 & 11.50 \\
Jamaica 1 & 18.7 & 4.76 & 0.099 & 12.41 & 14.39 \\
Jamaica 3 & 22.6 & 5.39 & 0.077 & 13.17 & 18.86 \\
Jamaica 4 & 17.7 & 4.89 & 0.087 & 13.14 & 14.36 \\
Jamaica 5 & 24.3 & 5.28 & 0.078 & 13.94 & 21.81 \\
Jamaica 8 & 18.6 & 4.85 & 0.089 & 12.27 & 15.13 \\
Jamaica 10 & 22.8 & 5.31 & 0.075 & 11.24 & 20.16 \\
Larsen & 20.0 & 5.20 & 0.074 & 7.68 & 16.74 \\
Mary Fancy & 21.2 & 4.92 & 0.075 & 11.33 & 17.11 \\
Morming Star & 22.1 & 5.06 & 0.068 & 12.02 & 17.44 \\
Ponce & 18.4 & 5.19 & 0.057 & 10.39 & 16.05 \\
Prolific & 18.5 & 5.09 & 0.077 & 14.49 & 15.80 \\
Russel & 18.2 & 5.16 & 0.555 & 11.63 & 14.66 \\
Timothe & 24.0 & 5.00 & 0.054 & 13.55 & 20.66 \\
\hline
\end{tabular}

The range of values for all varieties was 15.2 to 24.3 degrees Brix, 4.76 to $5.39 \mathrm{pH}, 0.054$ to $0.109 \%$ acidity, 7.68 to $15.19 \%$ reducing sugars and 11.50 to $21.81 \%$ total sugars. Bocksberg showed the lowest degrees Brix and percentage total sugars whereas Jamaica 5 showed the highest in both cases. It may be noted that Bocksberg variety averaged the lowest value as to flavor whereas Jamaica 5 averaged second highest.

Jamaica 1 had the lowest $\mathrm{pH}$ whereas Jamaica 3 had the highest $\mathrm{pH}$. Timothe showed the lowest percentage of acidity whereas Bocksberg showed the highest. Larsen had the lowest percentage of reducing sugars; Adelaide had the highest.

Data on production of the 17 sapodilla varieties for three consecutive years are presented in tables 3,4 and 5 . The Larsen variety produced the highest number of commercial fruits in $1985-86$ as well as the highest commercial yield $(\mathrm{kg})$ per tree during the same year and in 1982-83. Larsen was rated as the highest in regard to flavor. In 1982-83 and 1984-85, Blackwood was the best performer in regard to number of commercial fruits, and in 1984-85, in commercial yield per tree.

The highest mean weight of commercial fruits ( $\mathrm{g} / \mathrm{fruit}$ ) was 210.5 for Jamaica 4 in 1982-83; 180.6 for Jamaica 5 in 1984-85; and 243.1, for Jamaica 4 variety in 1985-86. The lowest mean weight of commercial fruits (g/fruit) was 61.0 for Mary Fancy in 1982-83; 68.5, for Jamaica 8, in 1984-85; and 69.4, for Jamaica 1 in 1985-86. 


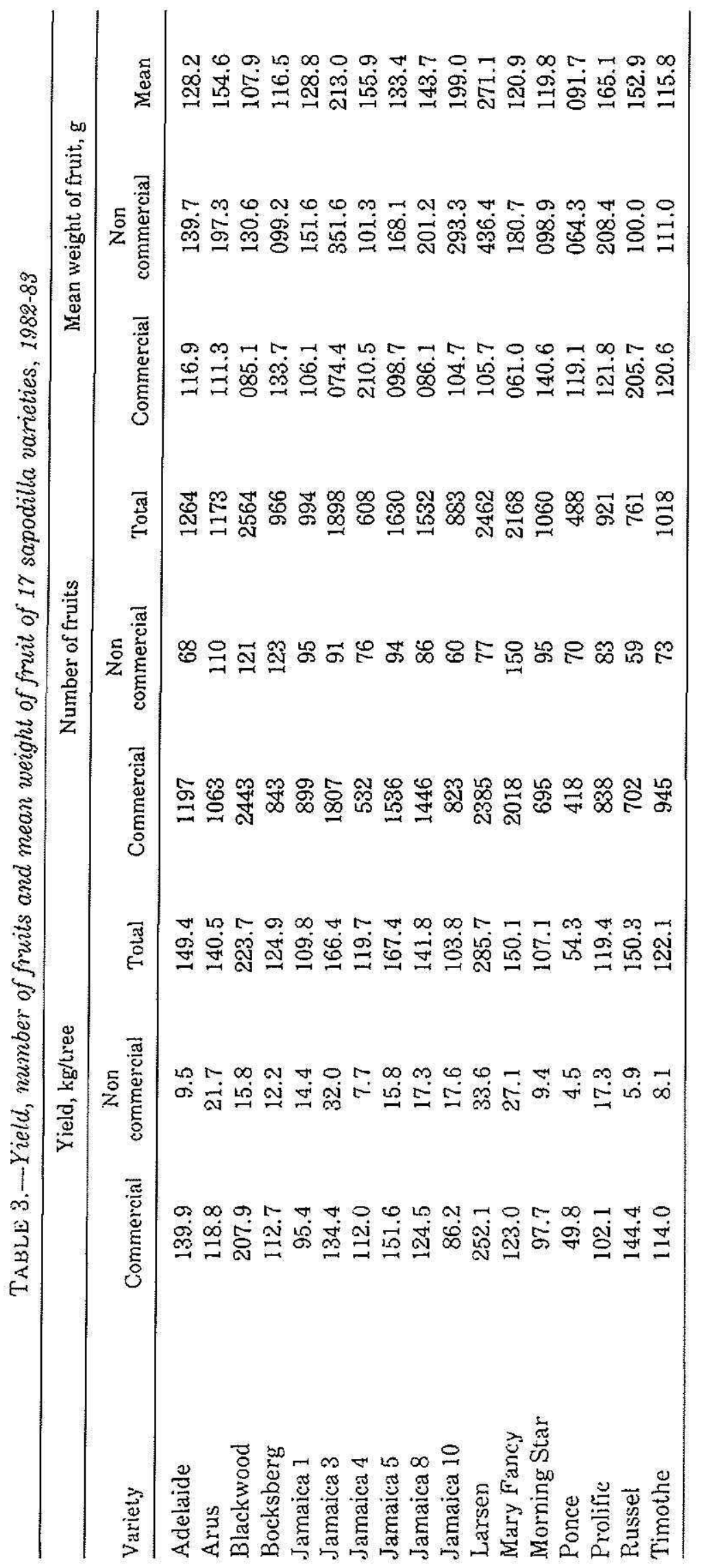




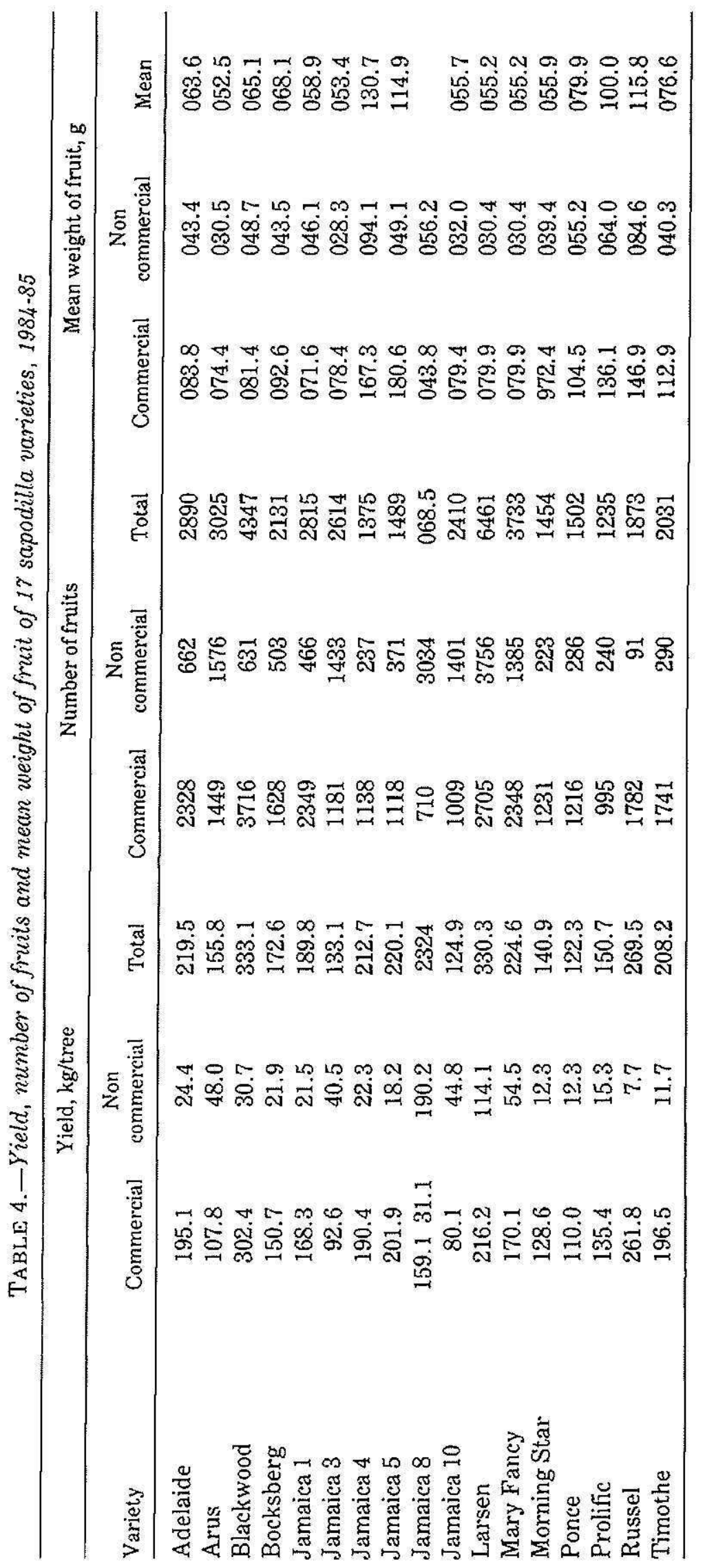




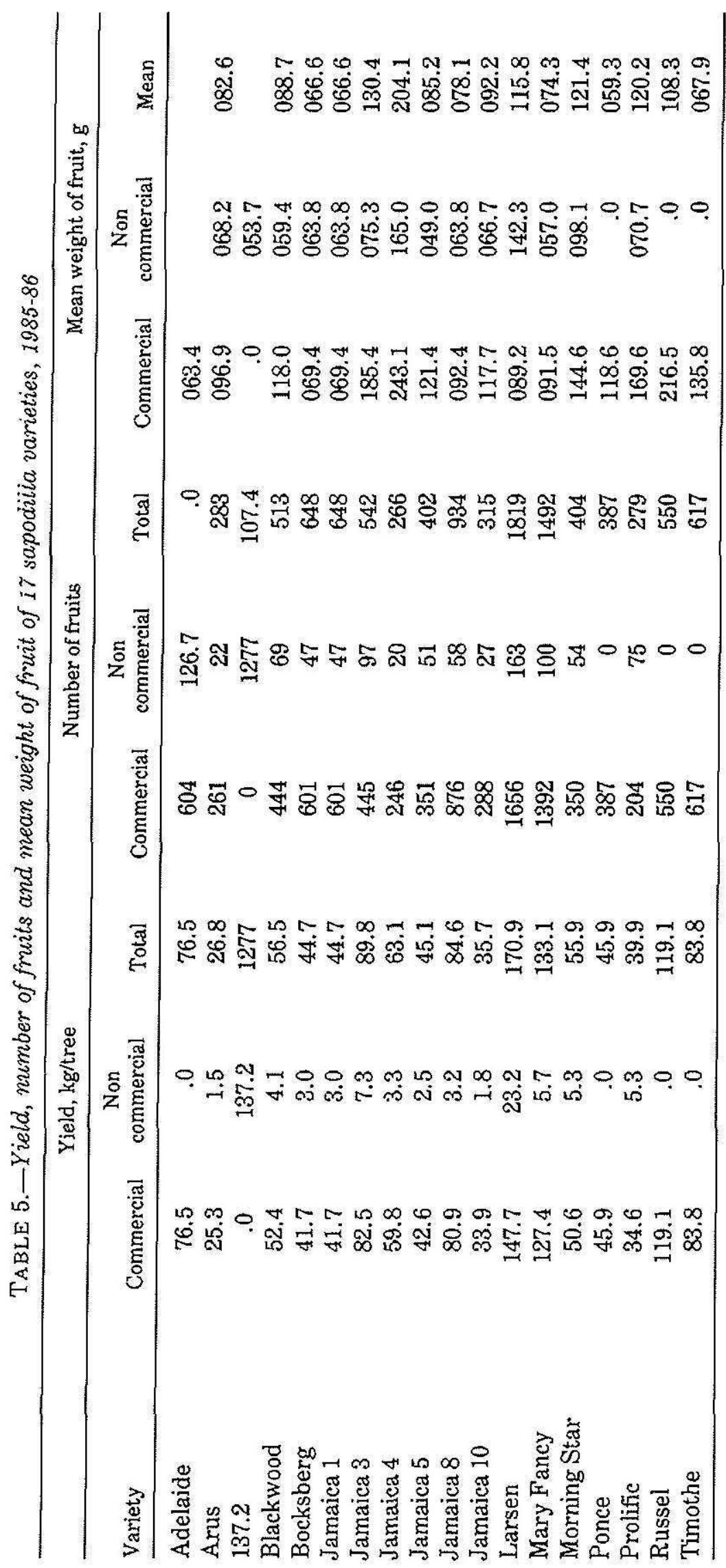


This study suggests that, considering all characteristics evaluated, varieties Larsen, Jamaica 5, Russel, Prolific, Morning Star and Timothe are the most promising for commercial production.

\section{LITERATURE CITED}

1. Amba Dan., 1985. Sapodilla, a delicious dehydrated product. Indian Hort. 30 (3): 13. Indian Inst. Hort. Res., Bangalore-560 080, India.

2. Ingle, G. S., D. M. Khedkar and R. S. Dabhade, 1982a. Effect of growth regulators on ripening of sapota fruit (Achras sapola Linn.). Indian Food Packer 36 (1): 72-7. Dept. Horticulture, Marathwada Agrie. Univ., Parbhani-431, 402, India.

3. __ _ and __ 1982b. Physico-chemical changes during growth of sapota fruit (Achras sapota Lim.). Indian Food Packer 36 (4): 86-94. Dept. Horticulture, Marathwada Agric. Univ. Parbhani-431 402, India.

4. Little, E., H. Wadsworth and J. Marrero, 1967. Arboles comunes de Puerto Rico $y$ las Islas Vírgenes. Editorial Univ. P. R., pp 624-76.

5. MacLeod, A. J. and N. González de Troconis, 1982. Volatile flavor components of sapodilla fruits (Achras sapota L.). J. Agric. Food Chem. 30 (3): 515-517. Dept. Chemistry, Queen Elizabeth Coll., Univ. of London, Campden Hill Road, London W8 $7 \mathrm{AH}$, United Kingdom.

6. Mowry, H., and L. R. Toy, Miscellaneous Tropical and Subtropical Florida Fruits. Revised by H. S. Wolfe. Florida Cooperative Extension, pp 129-32.

7. Ramadan, L. de, M. Mendoza, M. Ozuna and C. Panzza, 1983. Changes in sugar, texture and soluble solids in sapodilla plum (Achras sapola) var. Concludo. Revista Facultad de Agronomia, Universidad de Zulia 6 (2): 744-57. Universidad del Eto. Zulia, Maracay, Venezuela.

8. Rivas, N. R. and C. de Martos, 1982. Preservation of the pulp of sapota fruit (Achras sapota L.) by canning and freezing. Proc. Trop. Reg. Am. Soc. Hort. Sci. 22, 62-81. Univ. Cent. de Venezuela, Maracay, Venezuela.

9. Torres-Sepúlveda, A., 1976. El Níspero: Un frutal delicioso que se adapta bien a la costa sur de Puerto Rico. Revista del Café, pp 8-12. 